Grzegorz Wąchol, Wartości duchowe jako odpowiedź na zjawisko

konsumpcjonizmu, [w:] Cztowiek w relacji do... Rozważania o cztowieku jako

istocie relacyjnej, red. Grzegorz Wąchol, Kraków 2020, s. 87-101.

DOI: http://dx.doi.org./10.15633/9788374388740.06

KS. DR GRZEGORZ WĄCHOL

\title{
Wartości duchowe jako odpowiedź na zjawisko konsumpcjonizmu
}

\section{Konsumpcja we współczesnym społeczeństwie}

Współczesny świat jest coraz bardziej konsumpcyjny. Można to zauważyć, gdy słucha się przypadkowych rozmów na ulicy, obserwuje się zachowanie klientów sklepów czy wymienia się przemyśleniami podczas towarzyskiego spotkania. Widać to także po głębszej analizie współczesnej sytuacji społecznej na podstawie danych z zakresu socjologii, psychologii i ekonomii. Nie chodzi już o samo zjawisko konsumpcji, które jest czymś powszechnym i normalnym w cywilizacji dokonującejjakiegoś rozwoju. Jej poziom może być wyznacznikiem tego rozwoju, jeśli za jego kryterium przyjmiemy ogólne relacje ekonomiczne, jakie zachodzą w danej gospodarce.Jednocześnie na przykładzie krajów anglosaskich (głównie USA, Wielkiej Brytanii, Australii) oraz naszej ojczyzny widać, że wzrost konsumpcji (rozumianej jako przyrost liczby przetwarzanych dóbr) wcale nie musi iść w parze z rozwojem duchowym czy psychicznym, charakteryzowanym m.in. przez ogólną ocenę jakości życia. Mieszkańcy wspomnianych miejsc wcale nie deklarowali większego poczucia szczęścia 
wraz z rozwojem ekonomicznym. W przypadku Polski było wręcz przeciwnie: najwyższą deklarację zadowolenia z życia złożyli przed kilkoma laty przedstawiciele województwa lubelskiego, podkarpackiego i podlaskiego, a więc najbiedniejszych regionów w kraju1.

Konsumpcja przejawia się w różnych obszarach życia społecznego i w powszechnym ujęciu nie stanowi żadnej patologii. Jest zjawiskiem pomagającym w określeniu stanu danej społeczności. Ma swoje odniesienie w handlu, ekonomii, przemyśle, ale również w socjologii, psychologii czy pedagogice, kiedy pokazuje, jakie wartości są wybierane przez dane grupy społeczne ${ }^{2}$. Konsumpcja jest też czynnikiem napędzającym gospodarki, gdyż generuje popyt na określone towary. W krajach rozwijających się obserwujemy stały wzrost konsumpcji, będącej jednym z wyznaczników wzrostu gospodarczego ${ }^{3}$.

Warto przytoczyć etymologię omawianego terminu, która ukazuje przestrzeń semantyczną ukrytą za danym słowem. Łacińskie consumere oznacza dosłownie „zjadać”, „używać”, ale według Matego stownika tacińsko-polskiego to dopiero trzecie znaczenie tego słowa. Pierwszym i drugim są „niszczyć” i „zmniejszać”4.

\section{Konsumpcyjne wskaźniki rozwoju}

Niniejsze opracowanie nie będzie omawiać zjawiska konsumpcji, zajmie się raczej kwestią konsumpcjonizmu, czyli sposobu myślenia i życia skupionego wokół tego, by posiadać coraz więcej dóbr (najczęściej materialnych). Istotą konsumpcjonizmu, według

1 Por. A. Duda, Konsumpcja - teorie i badania, Lublin 2016, s. 350-351.

2 Por. T. Słaby, Konsumpcja - eseje statystyczne, Warszawa 2006, s. 11-14.

3 Por. A. Duda, Konsumpcja..., dz. cyt., s. 99.

4 Por. Maty stownik tacińsko-polski, red. J. Korpanty, Warszawa 2001, s. 141. 
Samuela Straussa, jednej z pierwszych osób, które podjęły publiczną dyskusję na ten temat, jest ciągłe podnoszenie lub przynajmniej utrzymywanie wysokiego standardu życia ${ }^{5}$.

To jedno z pierwszych i zarazem najprostszych określeń tego, czym jest konsumpcjonizm, dobrze oddaje jego istotę. Dzisiaj ludzie chcą żyć coraz lepiej, w różnych wymiarach: chcą posiadać więcej w portfelach, jeździć na bardziej luksusowe wakacje, ubierać się w markowe ubrania, mieć wysokofunkcjonalny sprzęt RTV i AGD. Widać to w wielu aspektach, choćby w tym, że kondycję danego kraju określa się po jego zasobach i zdolnościach ekonomicznych. Poziom życia jest sztywno związany ze średnimi dochodami $\mathrm{w}$ przeliczeniu na osobę lub realnymi możliwościami nabywania dóbr. W ocenie społeczeństw rzadko analizuje się np. wartości moralne, stan więzi rodzinnych, sposób przeżywania wolnego czasu czy zadowolenie z życia. Oczywiście są prowadzone badania sprawdzające wymienione tutaj czynniki, ale w powszechnej opinii jakość życia przelicza się na pieniądze. Głównym wskaźnikiem rozwojowym wciąż pozostaje PKB (produkt krajowy brutto), czyli liczba wyprodukowanych dóbr wyrażona w konkretnej walucie i przeliczona na głowę każdego mieszkańca. Możemy jednak zauważyć, że nie jest to w pełni wiarygodny miernik dobrobytu, co zauważa te $\dot{z}$ autor tekstu na ten temat w Encyklopedii PWN Sławomir Sztaba. Pokazuje on wiele innych aspektów, które nie są brane pod uwagę przy takim sposobie określania dobrobytu; są to m.in. subiektywne poczucie zaspokojenia potrzeb, efekty wynikające z produkcji środków czy faktyczny podział dóbr pomiędzy różne warstwy społecz$n e^{6}$. Gdyby wziąć pod uwagę ten ostatni wskaźnik, to okazałoby się,

5 Por. W. Leach, Land of Desire. Merchants, Power, and the Rise of a New American Culture, New York 1994, s. 266.

6 Por. S. Sztaba, Mierniki dobrobytu, w: Encyklopedia PWN, https://encyklopedia.pwn.pl/haslo/mierniki-dobrobytu;3940747.html (7.05.2019). 
że tzw. najbardziej rozwinięte państwa świata dokonują w jakimś sensie regresu (przynajmniej rozumianego w kategoriach sprawiedliwości społecznej). Dla przykładu w Stanach Zjednoczonych w latach 1960-1980 jeden procent najbogatszych Amerykanów posiadał 10 proc. sumy ogólnego dochodu państwa. W 2006 roku ten sam odsetek społeczeństwa posiadał już 20,3 proc. wszystkich dochodów w państwie ${ }^{7}$.

Intuicję o niekomplementarności oceny jakości danego społeczeństwa za pomocą wskaźników ekonomicznych potwierdza polskie badanie CBOS z 2018 roku na temat poczucia jakości życia Polaków. Wśród najważniejszych czynników decydujących o szczęściu nasi rodacy wskazali relacje przyjacielskie i rodzinne (83 proc.), rodzicielstwo (72 proc.) oraz małżeństwo lub nieformalny związek (65 proc.) i dopiero na czwartym miejscu warunki materialne (62 proc.), przy czym same dochody finansowe stanowiły o szczęściu zaledwie co trzeciego respondenta (31 proc.) ${ }^{8}$.

Podobne opinie prezentują ankietowani przez autora uczniowie szkół średnich (U) oraz studenci Uniwersytetu Rolniczego i Uniwersytetu Jagiellońskiego (S) w Krakowie. Badania były przeprowadzane w lutym i marcu 2019 roku, wzięło w nich udział łącznie 61 studentów w wieku od 21 do 32 lat i 87 uczniów w wieku od 17 do 19 lat. Respondenci wypełniali kwestionariusz składający się w większości z pytań zamkniętych z możliwością wielokrotnego wyboru lub nadania rangi zaproponowanym wartościom. W kilku przypadkach można było wpisać samodzielnie odpowiedź. Pytania dotyczyły sposobu konsumowania towarów i usług przez samych zainteresowanych oraz ich rodziny, a także ich rodzaju.

7 Por. G. Łyś, Każdy ktos na wagę ztota, „Rzeczpospolita” 2015, 21 marca, https://archiwum.rp.pl/artykul/1271483-Kazdy-klos--na-wage-zlota. html (20.03.2020).

8 Por. Centrum Badania Opinii Społecznej, Zadowolenie z życia, komunikat z badań, Warszawa 2018. 
Badani za najważniejszą wartość w swoim życiu uznali rodzinę ( $\mathrm{S}=44$ proc., $\mathrm{U}=45$ proc.), na drugim miejscu Boga ( $\mathrm{S}=31$ proc., $\mathrm{U}=17$ proc.) lub zdrowie ( $\mathrm{S}=20$ proc., $\mathrm{U}=25$ proc.). Pieniądze i kariera zawodowa były wybierane najczęściej jako czwarta lub piąta w kolejności wartość. Jednocześnie obydwie badane grupy wysoko oceniły przyjemność z zakupów i chęć podejmowania takiej aktywności (w skali od 1 do 5 było to: $\mathrm{S}=4,0 ; \mathrm{U}=4,3)^{9}$.

\section{Kultura konsumpcyjna wartości niematerialnych}

Konsumpcjonizm przejawia się nie tylko w materialnym wymiarze ludzkiego istnienia obrazowanym przez wielkie galerie handlowe, gdzie można nabyć towary z całego świata (wśród nich wiele do niedawna było egzotycznych), nie tylko poprzez promocje, oferty sprzedaży lub nowoczesne gadżety elektroniczne. Konsumpcjonizm wchodzi również w świat wartości wyższych, czyli niezwiązanych bezpośrednio z ekonomią. Wśród nich przykładem mogą być tzw. karty unlimited, które uprawniają za stałą miesięczną opłatą do nieograniczonego korzystania z kina. Sztuka z wartości podniosłej, nietuzinkowej, rzadkiej stała się kolejnym towarem na sprzedaż i do skonsumowania w bezgranicznej ilości. Podobną funkcję spełniają muzyka w słuchawkach pasażerów autobusu czy obrazy na ich smartfonach, z tym że jest to mniej kosztowne. Także nauka niestety przesiąka konsumpcjonizmem. Osoby zajmujące się nią często muszą wyprodukować określoną liczbę publikacji w danym czasie lub zdobyć wyższe kwalifikacje, niekiedy potwierdzone jedynie certyfikatem, a nie rzeczywistymi umiejętnościami. W ten sposób przechodzimy z pozycji doświadczonego mędrca i mistrza na rzecz wykwalifikowanego eksperta. Oczywiście obydwa sposoby

9 Badania własne. 
funkcjonowania mogą być zbieżne ze sobą, ale jednak często można odczuć, że nie są ${ }^{10}$. Konsumpcjonizm wszedł nawet do świata religii - wystarczy spojrzeć na gigantyczną halę handlową z dewocjonaliami pod bazyliką Matki Bożej z Guadalupe w Meksyku (podobnie w wielu innych sanktuariach świata) czy na protestanckie tzw. megakościoły w południowych stanach USA, mogące pomieścić w sobie nawet kilka tysięcy ludzi i świadczące szereg usług z zakresu pielęgnacji kosmetycznej, rozrywki, doradztwa finansowego i ubezpieczeniowego ${ }^{11}$. Innym przykładem zjawiska patologicznej konsumpcji wartości niemierzalnych empirycznie może być bigoreksja (nadmierna dbałość o piękno fizyczne) i związane $z$ nią uzależnienie od ćwiczeń, klasyfikowane już jako jedna $\mathrm{z}$ form nałogu behawioralnego ${ }^{12}$.

\section{Przyczyny nastawienia konsumpcyjnego}

Opisując konsumpcjonizm, można wskazać na wiele jego cech, ale na potrzeby tego opracowania, wkomponowanego w tematykę związaną z relacjami interpersonalnymi, uwypuklony zostanie jego wymiar temporalny. Niezależnie od tego, co jest konsumowane, odbywa się to z nastawieniem na „teraz”. Chodzi nie tyle o aktualny, konkretny moment w czasoprzestrzeni, ile o teraźniejszość rozumianą szerzej i odnoszącą się do ziemskiego życia człowieka, które można określić przez parametry fizjologiczne. W efekcie konsumpcjonizm staje się przejawem braku odniesienia do wartości

10 Por. T. Olchanowski, Kultura manii, Warszawa 2016, s. 161-180.

11 Por. J. Micklethwait, A. Wooldridge, Powrót Boga-jak globalne ożywienie wiary zmienia świat, tłum. J. Grzegorczyk, Poznań 2011, s. 205-210.

12 Por. M. Rowicka, Bigoreksja i uzależnienie od íwiczeń, „Świat Problemów” 209 (2015) nr 6, s. 28-30. 
ponadczasowych, wiecznych, w tym przede wszystkim do Boga lub innego absolutu rozumianego w jakikolwiek sposób właściwy dla danej religii lub indywidualnych poglądów. Zygmunt Bauman ujął ten kluczowy dla konsumpcjonizmu czynnik jako zastąpienie lęku przed życiem lękiem przed śmiercią ${ }^{13}$. Ludzkość w trakcie rozwoju cywilizacji stopniowo eliminowała kolejne zagrożenia, jakie wynikają z interakcji ze światem natury, podatności na choroby, słabej opieki medycznej, otwartych konfliktów zbrojnych (chociaż występuje ich wciąż bardzo wiele, to jednak w dużej mierze zostały one przeniesione w okowy zawodowych armii), głodu i innych problemów wystawiających zdrowie lub życie na ryzyko. W związku z tym zjawisko śmierci przeniosło się z codzienności za szpitalne lub hospicyjne mury, a oglądanie martwych ciał najbliższych nie jest normalnym doświadczeniem, a raczej praktyką podejmowaną na życzenie zainteresowanych. Człowiek zatem skupił się mocno na tym, co teraźniejsze, zaczął coraz bardziej „być na czasie” i inwestować w to, co mogło fundować jego tożsamośćc ${ }^{14}$.

$\mathrm{W}$ efekcie powszechne postrzeganie śmierci, nawet w obrębie kultury przesiąkniętej chrześcijaństwem, diametralnie się zmieniło. Już nie jest ona, jak uczy Katechizm Kościota katolickiego, konsekwencją grzechu pierworodnego, stanowiącą przejście do życia wiecznego ${ }^{15}$, a raczej przykrą koniecznością, przejawem pesymizmu i totalnej beznadziei, której nie da się opanować w żaden sposób i która niszczy życie w całości ${ }^{16}$. Brak nadziei na życie wieczne po

13 Por. Z. Bauman, Ponowoczesność jako źódto cierpień, Warszawa 2000, s. 256; za: P. Kopiec, Konsumpcjonizm. Perspektywa protestanckiej koncepcji cztowieka i spoteczeństwa, Lublin 2016, s. 62-63.

14 Por. W. Bołoz, Historyczne i wspótczesne postawy wobec śmierci, „Studia Ecologiae et Bioethicae" 3 (2005), s. 173-186.

15 Por. Katechizm Kościoła katolickiego, 402-412.

16 Por. R. Kokoszka, Umieranie i śmierć Jana Pawta II znakiem dla wspótczesnego śrwiata, „Studia Włocławskie” 9 (2006), s. 213-219. 
śmierci powoduje spadek częstotliwości i jakości praktyk religijnych, co szczególnie widać wśród chrześcijan w Kościołach cywilizacji zachodniej. To zjawisko przybiera charakter układu zamkniętego, gdyż jednocześnie przyczynia się do rozpowszechniania niewiary w zbawienie ${ }^{17}$. Bardziej powierzchowne przeżywanie swojej religii objawia się przejściem od osobistej relacji z Bogiem, który dzięki odkupieńczej misji Jezusa Chrystusa i Jego zmartwychwstaniu daje szansę na pokonanie śmierci, do formalnego uczestnictwa w grupie wierzących, pozbawionego duchowej głębi i związanego z zewnętrznymi praktykami ${ }^{18}$.

Dodatkowo neopozytywistyczny paradygmat empirycznego podejścia do poznawania świata, trwała obecność filozofii marksistowskiej w różnych wydaniach w cywilizacji zachodniej oraz rehabilitacja poglądów starożytnych sofistów nie pozwoliły na poszukiwanie wartości metafizycznych. Warto wspomnieć, że mniej więcej do przełomu XVIII i XIX stulecia myślano w kategoriach platońsko-arystotelesowskich, w których było miejsce na idee dające trwałe wyznaczniki tego, do czego należy zmierzać, oraz na obiektywne wartości, z których należy czerpać. Głównie za sprawą dowartościowania poglądów Protagorasa, czołowego przedstawiciela myśli sofistycznej, uznano powszechnie, że jedynie pragmatyzm ma sens. Nie można mieć pewności czegokolwiek nieweryfikowalnego empirycznie, $\mathrm{w}$ świecie istnieje pełny relatywizm i brak w nim obiektywnych spostrzeżeń, stąd każdy może mieć swój światopogląd, a społecznie powinien panować pewien konwencjonalizm, czyli zbiór zasad, na jakie się umówimy ${ }^{19}$.

17 Por. P. J. Chmura, Praktyki religijne w nauczaniu Kościota ostatnich lat, „Еódzkie Studia Teologiczne” 18 (2009), s. 43-60.

18 Por. Meliton z Sardes, Homilia paschalna, w: Pierwsi świadkowie. Pisma Ojców Apostolskich, red. M. Starowieyski, tłum. A. Świderkówna, Kraków 2010, s. 308-332.

19 Por. W. Tatarkiewicz, Historia filozofi, t. 1, Warszawa 2009, s. 72-78. 


\section{Zagrożenie dla relacji osobowych}

I tutaj dopiero pojawia się problem, jaki stanowi dla relacji zjawisko konsumpcjonizmu. Wobec opisanych do tej pory realiów bardzo trudno o zdrowe odniesienie do innych ludzi, gdyż nie są oni w stanie w empiryczny sposób dowartościować człowieka i wskazać na jego tożsamość. Ludzkość popada coraz bardziej w fałszywe przekonanie, że o jakości życia decyduje liczba i wartość posiadanych dóbr lub osiągniętych doczesnych celów, np. odwiedzonych miejsc ${ }^{20}$. Taka postawa powoduje zwiększający się głód kolejnych dóbr, mających służyć temu, by w myśl przytoczonej na samym początku głównej idei konsumpcyjnej poprawiać lub przynajmniej utrzymywać dotychczasowy status społeczny, wyrażany $\mathrm{w}$ dużej mierze przez stan posiadania materialnego. Zgodziła się z tym większość ankietowanych uczniów (64 proc.) i studentów $(57 \text { proc. })^{21}$. Te poglądy skrzętnie wykorzystują producenci różnych towarów, aby móc zarobić na pragnieniach obywateli współczesnego świata.

Przeniesienie pragnień i marzeń w sferę potrzeb - uczynienie z nich konieczności życiowej - jest jedną z cech i jednocześnie jednym ze skutków konsumpcjonizmu. To, czego ch c e my, musi zaistnieć realnie, nie może być jedynie daleką ideą, jakimś odległym planem (co współgra z przejściem od myślenia platońskiego do sofistycznego) ${ }^{22}$.

Inne przejawy konsumpcjonizmu zagrażające relacjom interpersonalnym to: skupienie się na przedmiocie, uzależnienie

20 Por. P. Kopiec, Konsumpcjonizm, dz. cyt., s. 55-61.

21 Badania własne.

22 Por. A. Karczewska, Globalizacja i konsumpcjonizm jako uwarunkowania zmian i potencjalne źródta zagrożeń w sferze pracy, „Zeszyty Naukowe Politechniki Częstochowskiej - Zarządzanie” 2 (2016) nr 24, s. 38-46. 
osobistych kontaktów i relacji od tego, co można przez nie zyskać, ponadwymiarowe godziny pracy powodujące przemęczenie i stres, brak czasu na dobrą komunikację (tutaj warto przypomnieć, że słowo „komunikacja” to zlepek dwóch łacińskich terminów: communio i actio, a więc dosłownie „działanie na rzecz wspólnoty”, a nie wyłącznie przekaz informacji), złe relacje na płaszczyźnie ekonomicznej, uzależnienia chemiczne wynikające $\mathrm{z}$ nadużywania substancji mających rekompensować stres i samotność, uzależnienia behawioralne (np. uzależnienie elektroniczne, zakupoholizm), sprowadzenie głębokich relacji do płytkich przeżyć (np. rozumienie miłości jako wymiany wzajemnych korzyści), stygmatyzacja osób niewpisujących się w ramy piękna w imię tzw. kultu ciała (np. chorych psychicznie, starszych, niepełnosprawnych), przesycenie dobrami i brak zdolności do zachwytu, komercjalizacja sztuki, uprzedmiotowienie ludzi (aż do skrajności w postaci niewolnictwa lub handlu organami), sprowadzenie kontaktu do świata wirtualnego, absolutyzacja nowinek technicznych ${ }^{23}$. Badani uczniowie zadeklarowali, że poświęcają trzykrotnie więcej czasu w ciągu dnia (4,5 godziny) na komunikację wirtualną niż na rozmowę z rodziną (1,5 godziny). Ci sami ankietowani wskazali również, że nie widzą sensu w uczeniu się lub przyswajaniu umiejętności, których nie wykorzystuje się w praktyce ( $\mathrm{U}=66$ proc.), co wskazuje na myślenie pragmatyczne, utylitarystyczne i na niedostrzeganie sensu w tym, co teoretyczne, w zdobywaniu wiedzy dla własnego rozwoju, a nie dla konkretnych, z góry zdefiniowanych celów. To również cechy towarzyszące konsumpcjonizmowi ${ }^{24}$.

23 Por. T. Biedrzycki, Konsumpcjonizm jako nowa kwestia spoteczna, „Studia Gdańskie” 21 (2007), s. 314-330.

24 Badania własne. 


\section{Drogi wyjścia z konsumpcyjnego świata}

Jakie są lekarstwa, by uzdrowić relacje zarażone konsumpcjonizmem lub już przez niego zniszczone? Tutaj wierzący mają łatwiej, bo mogą spełnić się i zrealizować nie przez posiadanie wielu ziemskich dóbr, ale przez odniesienie do Boga, a ich cel znajduje się nie w supermarkecie czy na aukcji internetowej, ale w niebie, wśród zbawionych. Chrystus podkreślał wielokrotnie prymat wartości duchowych nad cielesnymi, np. w słowach: „Nie troszczcie się więc zbytnio i nie mówcie: co będziemy jeść? co będziemy pić? czym będziemy się przyodziewać? Bo o to wszystko poganie zabiegają. Przecież Ojciec wasz niebieski wie, że tego wszystkiego potrzebujecie. Starajcie się naprzód o królestwo i o Jego sprawiedliwość, a to wszystko będzie wam dodane" (Mt 6, 31-33). Dlatego słynna piramida Maslowa ujmująca potrzeby cielesne jako najbardziej podstawowe nie jest wyznacznikiem w poszukiwaniu szczęścia i wyraża odwróconą hierarchię wartości w stosunku do chrześcijaństwa ${ }^{25}$.

Potrzebny jest też powrót do wartości, które będą obiektywnie rozumiane, innymi słowy: ważna jest odbudowa moralności także w dziedzinie ekonomii, o co wielokrotnie apelował czeski ekonomista Tomáš Sedláček ${ }^{26}$.

I wreszcie wartości duchowe. Są one największą szansą na odkrycie prawdziwego sensu życia, w którym nie potrzeby kompensowania braków nadmiernym konsumowaniem dóbr. Duchowość jest przestrzenią aktualną i powszechną dla wszystkich ludzi, chociaż często zapomnianą lub niedocenianąą . Aby duchowość stała się

25 Por. A. Wasiukiewicz, Niebezpieczna psychologia, Poznań 2017, s. 48-50.

26 Por. T. Sedláček, Ekonomia dobra i zła, tlum. D. Bakalarz, Warszawa 2011, s. 61.

27 Por. S. Wargacki, Duchowośc w kulturze ponowoczesnej, „Zeszyty Naukowe KUL” 59 (2016) nr 4 (236), s. 27-51; K. Skrzypińska, Dokąd zmierzam? 
czynnikiem kształtującym ludzkie życie, potrzebne jest prawdziwe zaangażowanie w przeżywanie ich. Nie mogą pozornie uspokajać pragnień ludzkiej duszy i stanowić jedynie placebo, którego właściwości nie są znane. Autentycznie przeżywana wiara w Boga daje pokój i buduje nadzieję, dzięki której człowiek nie musi zaspokajać wewnętrznej pustki ziemskimi dobrami ${ }^{28}$. Benedykt XVI przekonuje, że prawdziwa nadzieja, zdolna do zaspokojenia najgłębszych ludzkich pragnień, rodzi się z osobistej relacji z Chrystusem $^{29}$. Również Sobór Watykański II dostrzegł ogrom poczucia beznadziei pojawiającego się we wnętrzu ludzi pozbawionych wiary i swojego prywatnego odniesienia do Jezusa Chrystusa. Przemiany społeczne zachodzące bardzo gwałtownie w XX wieku, zmieniające podejście do wartości wśród całych narodów i oddalające od Boga, spowodowały powszechny brak nadziei, skutkujący wewnętrznym zagubieniem, pustką i ciągłym poszukiwaniem fundamentu ludzkiej egzystencji ${ }^{30}$. Jedynie wieczny Bóg może w pełni zaspokoić naturalną potrzebę życia, z jaką rodzi się każdy człowiek, i nadać sens jego życiu możliwy do odkrycia nie gdzieś na zewnątrz siebie, a we własnej duszy ${ }^{31}$. Osoba, która posiada w swoim sercu Boga, ma wszystko, czego potrzeba jej do szczęścia ${ }^{32}$.

Przydatna jest też umiejętność zatrzymania się, refleksji, włączenia tzw. zdrowego rozsądku, który na podstawie obserwacji

Duchowośc jako wymiar osobowości, „Roczniki Psychologiczne” 1 (2008), s. 39-57.

28 Por. M. Tatar, Chrzésíjańska nadzieja jako czynnik rozwoju cztowieka i świata w encyklice „Spe salvi” Benedykta XVI, „Warszawskie Studia Teologiczne" 22 (2009) nr 2, s. 121-132.

29 Por. Benedykt XVI, Spe salvi, 24-30.

30 Por. Sobór Watykański II, Gaudium et spes, 4-10.

31 Por. T. Krawczyńska-Zaucha, $W$ poszukiwaniu spetnienia, „Tarnowskie Studia Teologiczne" 34 (2015) nr 2, s. 115-128.

32 Por. J 14, 6. 
i doświadczenia podpowie, jak dokonywać rozsądnych wyborów i na jakie wartości stawiać, aby być człowiekiem spełnionym. Wreszcie potrzebna jest zdolność poświęcenia i oddania posiadanych dóbr innym (również w sferze niematerialnej), bo człowiek jest stworzony po to, by kochać. To go wyróżnia ze wszystkich stworzeń świata i tylko miłość może wypełnić ostatecznie wszystkie jego pragnienia, a ona jest codziennym oddawaniem siebie dla innych ${ }^{33}$.

$\mathrm{Na}$ koniec warto sięgnąć po słowa anonimowego niemieckiego myśliciela z XVI wieku nazwanego Frankfurtczykiem ze względu na miejsce jego pobytu w jednym $z$ tamtejszych klasztorów. W swoim dziele zatytułowanym Teologia niemiecka pisze następujące zdanie: „Kto ma coś własnego lub chce mieć, albo chętnie by miał, ten sam jest jego własnością"34.

\section{Wybrana bibliografia}

1. Benedykt XVI, Caritas in veritate, Kraków 2009.

2. Benedykt XVI, Spe salvi, Kraków 2007.

3. Biedrzycki T., Konsumpcjonizm jako nowa kwestia spoteczna, „Studia Gdańskie” 21 (2007), s. 314-330.

4. Bołoz W., Historyczne i wspótczesne postawy wobec śmierci, „Studia Ecologiae et Bioethicae" 3 (2005), s. 173-186.

5. Centrum Badania Opinii Społecznej, Zadowolenie z życia, komunikat z badań, Warszawa 2018.

6. Chmura P. J., Praktyki religijne w nauczaniu Kościota ostatnich lat, „Łódzkie Studia Teologiczne” 18 (2009), s. 43-60.

7. Duda A., Konsumpcja - teorie i badania, Lublin 2016.

33 Por. Benedykt XVI, Caritas in veritate, 78.

34 Frankfurtczyk, Teologia niemiecka, tłum. P. Augustyniak, Warszawa 2013, s. 140 . 
8. Frankfurtczyk, Teologia niemiecka, tłum. P. Augustyniak, Warszawa 2013.

9. Karczewska A., Globalizacja i konsumpcjonizm jako uwarunkowania zmian i potencjalne źródta zagrożeń w sferze pracy, „Zeszyty Naukowe Politechniki Częstochowskiej - Zarządzanie” 2 (2016) nr 24, s. 38-46.

10. Katechizm Kościota katolickiego, wyd. 2 popr., Poznań 2009.

11. Kokoszka R., Umieranie i śmierć Jana Pawta II znakiem dla wspótczesnego świata, „Studia Włocławskie”9 (2006), s. 213-219.

12. Kopiec P., Konsumpcjonizm. Perspektywa protestanckiej koncepcji cztowieka i spoteczeństwa, Lublin 2016.

13. Krawczyńska-Zaucha T., W poszukiwaniu spetnienia,„Tarnowskie Studia Teologiczne” 34 (2015) nr 2, s. 115-128.

14. Leach W., Land of Desire. Merchants, Power, and the Rise of a New American Culture, New York 1994.

15. Eyś G., Ka żdy ktos na wagę ztota, „Rzeczpospolita”2015, 21 marca, https://archiwum.rp.pl/artykul/1271483-Kazdy-klos--na-wage-zlota.html (20.03.2020).

16. Maty stownik tacińsko-polski, red. J. Korpanty, Warszawa 2001.

17. Meliton z Sardes, Homilia paschalna, w: Pierwsi świadkowie. Pisma Ojców Apostolskich, red. M. Starowieyski, tłum. A. Świderkówna, Kraków 2010, s. 308-332.

18. Micklethwait J., Wooldridge A., Powrót Boga - jak globalne ożywienie wiary zmienia świat, tłum. J. Grzegorczyk, Poznań 2011.

19. Olchanowski T., Kultura manii, Warszawa 2016.

20. Pismo Święte Starego i Nowego Testamentu w przektadzie z jezyków oryginalnych [Biblia Tysiąclecia], oprac. zespół biblistów polskich z inicjatywy benedyktynów tynieckich, wyd. 5, Poznań 2000.

21. Rowicka M., Bigoreksja i uzależnienie od ćwiczen, „Świat Problemów” 209 (2015) nr 6, s. 28-30. 
22. Sedláček T., Ekonomia dobra i zła, tłum. D. Bakalarz, Warszawa 2011.

23. Skrzypińska K., Dokąd zmierzam? Duchowośc jako wymiar osobowości, „Roczniki Psychologiczne”1 (2008), s. 39-57.

24. Słaby T., Konsumpcja - eseje statystyczne, Warszawa 2006.

25. Sobór Watykański II, Konstytucja duszpasterska o Kościele w świecie współczesnym Gaudium et spes, Poznań 2002.

26. Sztaba S., Mierniki dobrobytu, w: Encyklopedia PWN, https:// encyklopedia.pwn.pl/haslo/mierniki-dobrobytu;3940747.html (7.05.2019).

27. Tatar M., Chrześcijańska nadzieja jako czynnik rozwoju cztowieka i świata w encyklice „Spe salvi” Benedykta XVI, „Warszawskie Studia Teologiczne" 22 (2009) nr 2, s. 121-132.

28. Tatarkiewicz W., Historia fllozofii, t. 1, Warszawa 2009.

29. Wargacki S., Duchowośc w kulturze ponowoczesnej, „Zeszyty Naukowe KUL" 59 (2016) nr 4 (236), s. 27-51.

30. Wasiukiewicz A., Niebezpieczna psychologia, Poznań 2017. 
A/4 Uniwersytet Papieski

Tfon Jana Pawla II 